\title{
Choice of Graft Material at Primary CABG Influences Cardiac Death and Reintervention Rates
}

\author{
J.T. Christenson D. Vala B. Faidutti A. Kalangos \\ Clinic for Cardiovascular Surgery, University Hospital, Geneva, Switzerland
}

\section{Key Words}

Coronary artery bypass grafting $\cdot$ Internal thoracic artery - Conduits - Redo coronary artery bypass grafting · Long-term result. Graft material . Percutaneous transluminal coronary angioplasty

\begin{abstract}
Objectives: To evaluate long-term survival and need for reintervention (redo CABG or percutaneous coronary artery transluminal angioplasty, PTCA) as a result of graft materials employed at the primary coronary artery bypass grafting (CABG). Subjects and Methods: 2,327 patients who underwent primary CABG between 1980 and 1990 were followed with regard to survival and reintervention requirements for a period of 10 years. There were three groups of patients. In group 1, CABG was performed between 1980 and 1982 using veins only. Group 2 subjects had CABG done from 1983 to 1985 using veins and internal thoracic artery (ITA). Those in group 3 received two ITAs (double ITA) from 1985 to 1990. Redo CABG and PTCS were performed as needed. Results: The 10-year cumulative survival figures for the groups were $92.8 \%$ (group 1), 94.8\% (group 2) and 95.4\% (group 3 ). The difference between the groups was statistically significant ( $p<0.001$ ). Cardiac event-free survival was $74.4 \%$ (group 1), $83.5 \%$ (group 2) and 92.6\% (group 3),
\end{abstract}

\section{KARGER}

Fax +41613061234

E-Mail karger@karger.ch

www. karger.com

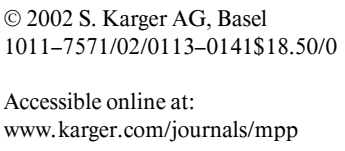

with $p<0.0001$. Myocardial infarction occurred more frequently in group 1 (4.7\%) than in groups 2 or 3 (2.2 and $1.3 \%$, respectively). The redo rates for CABG were $13.6 \%$ (group 1), 8.1\% (group 2), and 1.3\% (group 3). The corresponding PTCA rates for the three groups were 7.1, 3.7 and $1.6 \%$, respectively ( $p<0.0001$ ). Conclusions: Double ITA, compared with single ITA and/or vein grafts, was the optimal graft material at the time of primary CABG because it had the lowest reintervention rate. It also did not increase postoperative morbidity.

Copyright $\odot 2002$ S. Karger AG, Basel

\section{Introduction}

Numerous reports have emphasized the long-term survival superiority of double arterial conduits over veins in coronary artery bypass grafting (CABG) surgery [1-3]. Complete arterial revascularization has been strongly advocated $[4,5]$. The additional benefit of double internal thoracic artery (ITA) grafts has been more difficult to demonstrate [6-8], but a recent analysis from Cleveland Clinics, Cleveland, Ohio, USA based on a large patient population has clearly demonstrated the efficacy of double ITA grafting compared to single ITA in terms of longterm benefits [9]. However, because using double ITA grafts is time-consuming and cumbersome, most cardiac

Jan T. Christenson, MD

Clinic for Cardiovascular Surgery, University Hospital

Rue Micheli-du-Crest 24

CH-1211 Geneva 14 (Switzerland)

Tel. +41 22 3727630, Fax +4122 3727634, E-Mail Jan.Christenson@hcuge.ch 
Table 1. Preoperative patient characteristics for the three study groups (\%)

\begin{tabular}{llll}
\hline Parameters & $\begin{array}{l}\text { Group 1 } \\
\text { vein grafts only } \\
(\mathrm{n}=870)\end{array}$ & $\begin{array}{l}\text { Group 2 } \\
\text { single ITA + vein/s } \\
(\mathrm{n}=1,032)\end{array}$ & $\begin{array}{l}\text { Group 3 } \\
\text { double ITA grafts } \\
(\mathrm{n}=425)\end{array}$ \\
\hline Male gender & 88.9 & 90.0 & 89.9 \\
Mean age \pm SD & $58.4 \pm 9.6$ & $59.2 \pm 8.6$ & $60.1 \pm 8.8$ \\
Age $>$ 65 years & 9.5 & 12.3 & 11.8 \\
Insulin-dependent diabetes mellitus & 12.6 & 12.5 & 12.9 \\
Peripheral vascular disease & 7.4 & 6.6 & 7.5 \\
Preoperative NYHA classes III+IV & 54.8 & 55.0 & 54.6 \\
Extent of disease & & & 6.8 \\
$\quad$ Single & 6.7 & 6.5 & 6.2 \\
$\quad$ Double & 9.7 & 8.7 & 84.0 \\
$\quad$ Triple & 83.6 & 15.8 & 16.0 \\
LVEF $<0.40$ & 15.7 & 19.9 & 20.5 \\
Left main stenosis $>70 \%$ & 20.8 & & \\
\hline
\end{tabular}

LVEF = Left ventricular ejection fraction (measured from preoperative ventriculography).

centers still tend to accept the less efficient strategy at primary CABG, namely the use of one ITA graft together with vein graft/s, which has been shown to result in higher redo rates [10]. Also, redo CABG is known to be associated with a significantly higher hospital mortality and postoperative morbidity than primary CABG [10-14]. We report our experience using different surgical strategies on graft choice at the primary $\mathrm{CABG}$ operation on long-term survival and redo rates in patients with vein only, artery plus vein, or double ITA grafts.

\section{Subjects and Methods}

Study Population. In a retrospective analysis, 2,327 patients who had primary myocardial revascularization (CABG) between 1980 and 1990 was done. Special emphasis was placed on survival and reintervention requirements [percutaneous transluminal coronary angioplasty (PTCA) and/or redo CABG] during a minimum followup period of 10 years. Group 1 was comprised of 870 patients receiving only vein grafts, group 2 included 1,032 patients who received one ITA graft + vein graft/s, and group 3 had 425 patients who received double ITA grafts (group 3) for myocardial revascularization. Preoperative patient characteristics and coronary angiographic data are given in table 1. Patients undergoing emergency operations or combined cardiac procedures were excluded since this could have affected the choice of conduit. The patients were exclusively recruited from a local and stable population corresponding to the catchment area of the university hospital, thus ensuring simple, complete and accurate follow-up.

Definitions of Postoperative Morbidity. Myocardial infarction was defined as the appearance of new Q waves or significant loss of R- wave forces and mean peak creatine kinase MB fractions greater than $10 \%$ of total creatine kinase. Sternal dehiscence was defined as sternal instability which required sternal refixation. Hemorrhage was defined as required resternotomy for bleeding. Neurological events were defined as any transient or permanent neurological deficit that developed after CABG. Mediastinitis implied confirmed mediastinal infection at resternotomy together with positive cultures.

Statistics. All statistical analyses were performed using a computer software program (StatView ${ }^{\mathrm{TM}}$ version 4.5, Abacus Concepts, Berkeley, Calif., USA). Student's t test (one-sample paired test), Mann-Whitney, and Fisher's exact test were employed to assess differences between groups for statistical significance, where appropriate. A probability level of $\mathrm{p}<0.05$ was regarded as significant. Independent predictors for reintervention during follow-up were analyzed by multivariate analysis. Nonparametric estimates of survival (death from any cause including hospital deaths) and cardiac event-free survival (myocardial infarction and reinterventions such as redo CABG and PTCA) were calculated for each group by the Kaplan and Meier method.

\section{Results}

During the study period, there was no change in myocardial protection or the surgical techniques - only the choice of graft material changed, as defined below. For example, the pattern of coronary disease (table 1) and the average number of distal anastomoses $(2.4 \pm 0.7$, group 1; $2.6 \pm 0.9$, group $2 ; 2.6 \pm 0.8$, group 3 ) did not reveal any group differences.

The 10-year cumulative survival rate was significantly better when double ITA grafts were used at primary 


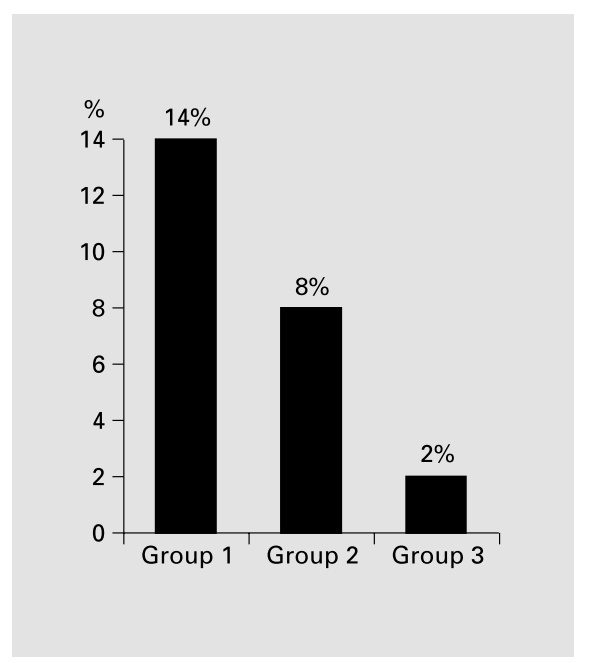

Fig. 1. Average yearly reoperation rates after myocardial revascularization with vein grafts only (group 1), one ITA + vein graft/s (group 2) and double ITA grafts (group 3).

CABG compared to when only veins were used as bypass conduits (group 3, 406 patients at risk, versus 92.8\%, group 1, 807 patients at risk; $\mathrm{p}<0.001)$ and better than when one ITA and vein graft/s were used $(94.8 \%$, group 2 , 981 patients at risk). Also cardiac event-free survival at 10 years was significantly better for group 3,92.6\%, compared to group 2, 83.5\% and group 3, 74.4\%, p $<0.0001$. Multivariate analysis identified only age above 65 years $(p=0.006)$, triple vessel coronary artery disease $(p=0.01)$ and use of only vein grafts at primary operation $(\mathrm{p}<$ 0.0001 ) as independent predictors for reintervention. Age higher than 65 years $(\mathrm{p}<0.0001)$, triple vessel coronary artery disease $(\mathrm{p}=0.005)$, use of only vein grafts at primary operation $(p<0.0001)$ and left ventricular ejection fraction less than $0.40(\mathrm{p}<0.0001)$ were identified as independent predictors of death, however, without group differences.

The average yearly reoperation rates following CABG for the three study groups are presented in figure 1 . The detailed yearly reoperation rate due to severe graft stenosis or graft occlusion is shown in figure 2 , and the shift in institutional policy regarding the use of ITA grafts is demonstrated in figure 3 . When grouping the patients according to time periods using 1985 as breaking point (the time when double ITA grafts were frequently used at the primary CABG operation), there was a highly significant drop in reoperation rates observed (table 2). There was no increased postoperative morbidity detected in the group

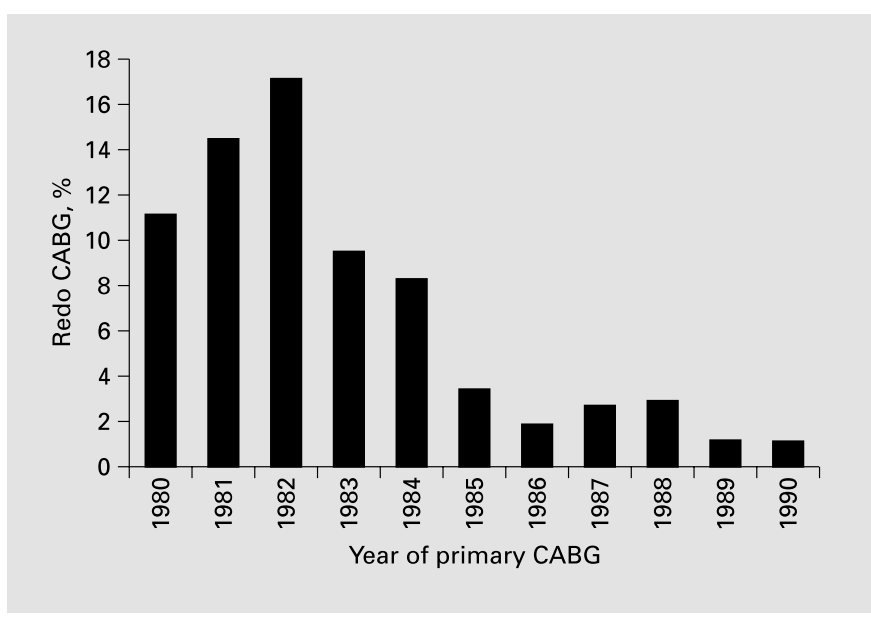

Fig. 2. Yearly reoperation rates for patients undergoing primary CABG surgery between 1980 and 1990.

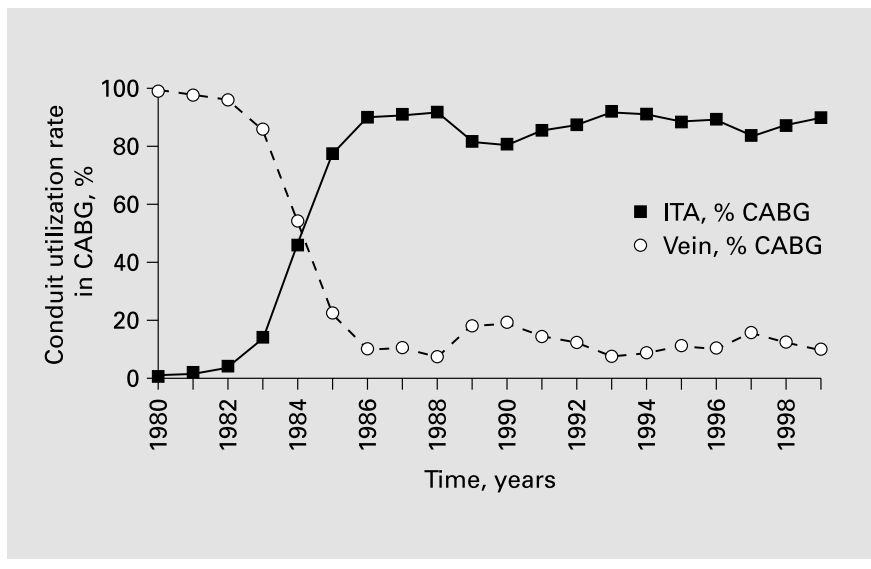

Fig. 3. The use of autologous saphenous vein and internal thoracic artery (ITA) as bypass conduit in primary CABG operations between 1980 and 1999.

Table 2. Average yearly reoperation rate following primary CABG in patients operated between 1980 and 1990 and followed for at least 10 years, comparing two time periods (mean $\pm \mathrm{SD}$ )

\begin{tabular}{lcc}
\hline Time period & Average reoperation rate & Range, $\%$ \\
\hline $1980-1985$ & $12.0 \pm 3.6 \%$ & $8.2-17.0$ \\
p value & $<0.0001$ & \\
$1986-1990$ & $2.2 \pm 0.9 \%$ & $1.1-3.4$ \\
\hline
\end{tabular}


Table 3. Postoperative morbidity comparing patients who received double ITA, single ITA + vein/s, and vein graft only, undergoing primary CABG between 1980 and 1990

\begin{tabular}{|c|c|c|c|}
\hline Parameters & $\begin{array}{l}\text { Group } 1 \\
\text { vein grafts only } \\
(\mathrm{n}=870)\end{array}$ & $\begin{array}{l}\text { Group } 2 \\
\text { single ITA + vein } / \mathrm{s} \\
(\mathrm{n}=1,032)\end{array}$ & $\begin{array}{l}\text { Group } 3 \\
\text { double ITA grafts } \\
(n=425)\end{array}$ \\
\hline Myocardial infarction & $4.7 \% \mathrm{p}<0.0001$ & $2.1 \% \mathrm{p}<0.0001$ & $1.2 \%$ \\
\hline Refixation of sternum due to sternal dishiscence & $1.0 \%$ & $0.7 \%$ & $0.9 \%$ \\
\hline Resternotomy for bleeding & $0.6 \%$ & $0.7 \%$ & $0.7 \%$ \\
\hline Mediastinitis & $0.0 \%$ & $0.2 \%$ & $0.2 \%$ \\
\hline Bleeding requiring blood transfusion & $0.6 \%$ & $0.7 \%$ & $0.7 \%$ \\
\hline Prolonged ventilatory support $>24 \mathrm{~h}$ & $25.3 \%$ & $26.7 \%$ & $24.7 \%$ \\
\hline Intensive care unit stay $>48 \mathrm{~h}$ & $18.1 \%$ & $16.2 \%$ & $15.5 \%$ \\
\hline
\end{tabular}

$\chi^{2}$ test was used. Statistically significant group differences are shown by $\mathrm{p}$ values. All other group differences were statistically not significant ( $\mathrm{p}>0.05)$.

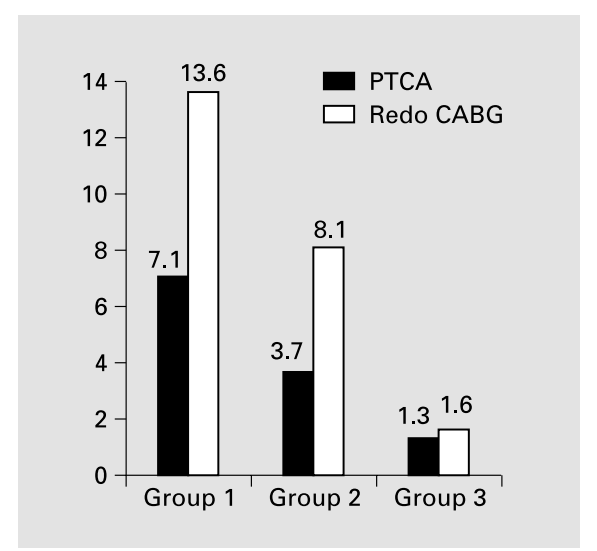

Fig. 4. Incidence of reinterventions (redo CABG or PTCA) 10 years following myocardial revascularization with vein grafts only (group 1), one ITA + vein graft/s (group 2) and double ITA grafts (group 3).

of patients who received double ITA grafts at the primary CABG operation compared to those who received only one ITA and/or only veins (table 3 ).

During follow-up myocardial infarction occurred more frequently in patients with only vein grafts (group 1, 4.7\%) compared to those with one ITA + vein/s (group 2, $2.1 \%)$ and those who had double ITA at primary CABG (group 3, 1.2\%), as shown in table 3. Reinterventions (PTCA and redo CABG) were more frequently required in patients with vein grafts, 7.1 and $13.6 \%$, respectively, compared to patients with one ITA graft + vein/s, 3.7 and $8.1 \%$, respectively, and those who received double ITA grafts, 1.3 and $1.6 \%$, respectively (fig. 4). Forty-four percent of reinterventions (PTCA and redo CABG) for groups 2 and 3 occurred within 5 years of the primary CABG, while only $29 \%$ of required reinterventions for group 1 patients occurred within the same time period.

At redo CABG, $91 \%$ of all ITA grafts were patent compared to only $40 \%$ patency rate for vein grafts, $p<0.001$.

Twelve percent of ITA grafts were used as sequential grafts, left anterior descending coronary artery and diagonal branches, and in 3\% the Y-graft technique was employed. Ninety-two percent of all ITA grafts were used as pediculated grafts while in $8 \%$ a free ITA graft was used, mainly to the circumflex area, without group differences. Complete revascularization was achieved in 73,72 and $70 \%$, respectively.

\section{Discussion}

\section{Changing Surgical Strategies on Choice of Conduits at Primary $C A B G$}

Prior to 1985 , autologous saphenous vein grafts were predominantly used as bypass conduits at our institution, comprising $99 \%$ of all grafts used in 1980 . The utilization of a single ITA graft as conduit was first introduced in 1980, and was increasingly used alone or together with vein grafts over the years to follow. However, after observing a steady increase in the yearly need for reopera- 
tive CABG rates: $11 \%$ in $1980,15 \%$ in 1981 and $17 \%$ in 1982 (fig. 2), and despite an increased utilization of single ITA grafts at the primary $\mathrm{CABG}$, the yearly reoperation rate was unacceptably high and therefore, the concept of using double ITA grafts was introduced in the later part of 1984. Double ITA grafts were used with great enthusiasm during the years to follow and only patients who had hemodynamic instability or lack of a suitable right ITA did not receive a second ITA graft (e.g. 40\% of all CABG received double ITA grafts in 1987 and 1988).

The importance of what conduit strategy was employed at the primary CABG operation is reflected in the long-term outcome, which has been repeatedly and convincingly demonstrated following the introduction of ITA as bypass conduit $[2,15,16]$. The ITA graft has a superior long-term patency rate compared to vein grafts and significantly fewer cardiac events and need for reoperative CABG during follow-up have been reported $[2,15,16]$. The use of ITA as a bypass conduit, particularly to the left anterior descending coronary artery, has become a standard in CABG surgery.

Use of double ITA grafts has shown that the completeness of myocardial revascularization also plays a role with regard to long-term outcome [4, 17], consistent with the findings of this study. However, the use of double ITA grafts was criticized because it was reported to be associated with increased postoperative morbidity and added operation room time $[18,19]$. It has also been difficult to demonstrate incremental benefits of double ITA grafting, mainly due to small study populations, short follow-up times and last but not least, difficulties due to patient selection bias in choosing one or the other graft material strategy $[6,7,20,21]$. In a recent retrospective study using a patient population of more than 10,000 patients from the Cleveland Clinics, Cleveland, Ohio, USA, Lytle et al. [9] were able to clearly demonstrate that patients who received two ITA grafts had a long-term decreased risk of death, reoperation and angioplasty [9]. The only morbid event that significantly differs between the use of one and two ITA grafts, respectively, was a slightly higher incidence of sternal wound complications when two ITA grafts were used [9].

Although our study had fewer patients, its major advantage was its high degree of standardization (less bias) because a smaller number of cardiologists and cardiac surgeons were involved in direct patient care and patients were recruited from a very stable patient population, which makes the follow-up data more readily available. We are therefore confident of our findings that the superior conduit strategy at the primary $\mathrm{CABG}$ operation is the use of double ITA grafts. Patients with double ITA grafts have a significantly lower risk of cardiac death as well as a decreased risk for reinterventions (PTCA and/or redo CABG) during long-term follow-up than patients who received either one ITA + vein graft/s or only vein grafts at the primary revascularization procedure. These results confirm the findings recently reported by Lytle et al. [9], but not those of another recent report which could not demonstrate an incremental benefit of two ITA grafts over unilateral ITA and vein grafts [22].

In contrast to previous reports $[9,18]$, we did not demonstrate an increased postoperative morbidity when double ITA grafts were used compared to single ITA use, and hospital mortality did not show group differences. In patients who present with two patent ITA grafts but a symptomatic progression of their native vessel atherosclerotic disease, PTCA can be performed with maximal security. Double ITA grafts can also be employed when surgical myocardial revascularization is performed in extremely high-risk coronary patients, provided preoperative intra-aortic counterpulsation therapy is given to diminish myocardial ischemia and that the patient is stabilized prior to aortic cross-clamping, which will allow ample time to prepare the two ITAs [23]. Even if double ITA grafting is more demanding and time-consuming, utilization of double ITA grafts ought to become the gold standard strategy at the primary CABG operation, since it has been demonstrated both in this study and others [9, $15,16]$ that double ITA grafting has superior long-term results.

\section{Conclusion}

Double ITA grafts at the time of primary CABG have been shown to be superior to single ITA and/or vein graft/s. Double ITA grafts reduce both the risk of cardiac death and need for subsequent reintervention, contributing to better prospects for long-term survival. 


\section{References}

1 Kirklin JW, Naftel CD, Blackstone EH, Pohost GM: Summary of a consensus concerning death and ischemic events after coronary artery bypass grafting. Circulation 1989;79:181-191.

2 Cameron A, Davis KB, Green G, Schaff HV: Coronary bypass surgery with internal-thoracic-artery grafts: Effects on survival over a 15year period. N Engl J Med 1996;334:216-219.

3 Loop FD, Lytle BW, Cosgrove DM, Stewart RW, Goormastic M, Williams GW, Golding LA, Taylor PC, Sheldon WC: Influence of the internal-mammary-artery graft on 10-year survival and other cardiac events. N Engl J Med 1986;314:1-6.

4 Lytle BW, Cosgrove DM, Saltus GL, Taylor PC, Loop FD: Multivessel coronary revasculariztion without saphenous vein: Long-term results of bilateral internal mammary artery grafts. Ann Thorac Surg 1983;36:540-547.

5 Sergeant P, Blackstone E, Meyns B: Validation and interdependence with patient-variables on the influence of procedural variables on early and late survival after CABG. K.U.Leuven Coronary Surgery program. Eur J Cardiothorac Surg 1997;12:1-19.

6 Pick AW, Orszulak TA, Anderson BJ, Schaff HV: Single versus bilateral internal mammary artery grafts: 10-year outcome analysis. Ann Thorac Surg 1997;64:599-605.

7 Fiore AC, Naunheim KS, Dean P, Kaiser GC, Pennington G, Williams VL, McBride LR, Barner HB: Results of internal thoracic artery grafting over 15 years: Single versus double grafts. Ann Thorac Surg 1990;49:202-209.
8 Berreklouw E, Schonberger JP, Ercan H, Koldewjin EL, de Bock M, Verwaal VJ, van der Linden F, van der Tweel I, Bavinck JH, Bredee JJ: Does it make sense to use two internal thoracic arteries? Ann Thorac Surg 1995;59:14561463.

9 Lytle BW, Blackstone EH, Loop FD, Houghtaling PL, Arnold JH, Akhrass R, McCarthy PM, Cosgrove DM: Two internal thoracic artery grafts are better than one. J Thorac Cardiovasc Surg 1999;117:855-872.

10 Ghali WA, Ash AS, Hall RE, Moskowitz MA: Variation in hospital rates of intraaortic balloon pump use in coronary artery bypass operations. Ann Thorac Surg 1999; 67:441-445.

11 Loop FD, Lytle BW, Cosgrove DM, Woods EL, Stewart RW, Golding LA, Goormastic M, Taylor PC: Reoperation for coronary atherosclerosis: Changing pattern in 2,509 consecutive patients. Ann Surg 1990;212:378-386.

12 Schmuziger M, Christenson JT, Maurice J, Mosimann E, Simonet F, Velebit V: Reoperative myocardial revascularization: An analysis of 458 reoperations and 2,645 single operations. Cardiovasc Surg 1994;2:623-629.

13 Loop FD, Cosgrove DM, Kramer JR, Lytle BW, Taylor PC, Golding LA, Groves LK: Late clinical and angiographic results in 500 coronary artery reoperations. $\mathbf{J}$ Thorac Cardiovasc Surg 1981;81:675-685.

14 Qasi A, Garcia JM, Mispireta LA, Corso PJ: Reoperation for coronary artery disease. Ann Thorac Surg 1981;32:16-18.

15 Lytle BW, Loop FD, Cosgrove DM, Ratliff NB, Easley K, Taylor PC: Long-term (5-12 years) serial studies of internal mammary artery and saphenous vein coronary bypass grafts. J Thorac Cardiovasc Surg 1985;89:248-258.
16 Okies JE, Page US, Bigelow JC, Krause AH, Solomon NW: The left internal mammary artery: The graft of choice. Circulation 1984; 70(suppl):I 213-221.

17 Buda AJ, McDonald IL, Anderson MJ, Strauss HD, David TE, Berman ND: Long-term results following coronary bypass operation: Importance of preoperative factors and complete revascularization. J Thorac Cardiovasc Surg 1981;82:383-390.

18 Kouchoukos NT, Waering TH, Murphy SF Pelate C, Marshall WG Jr: Results of bilateral internal mammary artery bypass grafts. Ann Thorac Surg 1990;49:210-217.

19 Lytle BW, Cosgrove DM, Loop FD, Borsh J, Goormastic M, Taylor PC: Perioperative risk of bilateral internal mammary artery grafting: Analysis of 500 cases 1971 to 1984. Circulation 1986;74:III 37-41.

20 Morris JJ, Smith LR, Glower DD, Muhlbaier LH, Reves JG, Wechsler AS, Rankin JS: Clinical evaluation of single versus multiple mammary artery bypass. Circulation 1990;82 (suppl):IV 214-223.

21 Naunheim KS, Barner HB, Fiore AC: Results of internal thoracic artery grafting over 15 years: Single versus double grafts. 1991 update. Ann Thorac Surg 1992;53:716-718.

22 Carrel T, Huber P, Turina M: Options for twovessel coronary artery disease: Midterm results of bilateral ITA grafts versus unilateral ITA and saphenous vein grafts. Ann Thorac Surg 1996;62:1289-1294.

23 Christenson JT, Simonet F, Schmutziger M: The effect of preoperative intra-aortic balloon pump support in high risk patients requiring myocardial revascularization. J Cardiovasc Surg 1997;38:397-402. 